\title{
Hiperreality Of Social Media: A Phenomenology Study of Self Confession of Housewives of Facebook Users
}

\author{
Nur Laili Damayanti ${ }^{*}$, Medhy Aginta Hidayat ${ }^{2}$ \\ ${ }^{1,2}$ Department of Sociology, Faculty of Social Science and Culture, \\ UniversitasTrunojoyo Madura \\ Jalan Raya Telang, PerumahanTeangInda, Telang, Kamal, Bangkalan, Indonesia \\ Email: damayantinurlaily@gmail.com \\ Email: medhy.hidayat@trunojoyo.ac.id
}

\begin{abstract}
The phenomenon of hyperreality that is occurring in the community is increasingly apparent through social media, especially mothers in Rengel Village. Hyperreality is formed by the existence of social media for housewives to get self-recognition through Facebook. The purpose of this study was to analyze the self-recognition of housewives using Facebook in Rengel Village, Tuban Regency. The theory used is Jean Baudrillard'sHyperreality theory that hyperreality is a symptom of the emergence of various artificial realities that are more real than the original. The method used in this research is qualitative research with a phenomenological study approach. Subject selection techniques in this study using purposive samples, data sources from this study used primary data and secondary data. Data analysis using data reduction, data models, concluding. And check the validity of the data using source triangulation. The results showed housewives get self-recognition through various ways, namely, through photo uploads using a beautiful camera so that results look perfect than reality, through Facebook status that shows everyday life in order to get a response from other Facebook users. Through photos daily activities so that other Facebook users know what is being done every day and get responses from other Facebook users. Through photos that are marked there are various beauty products to be more interested in the products offered.
\end{abstract}

Keywords: hyperreality, facebook, self confession

Submited: 2019-07-25; Accepted: 2019-10-17; Published: 2019-10-18

*Corresponding author : Email: damayantinurlaily@gmail.com 


\begin{abstract}
Abstrak
Fenomena hiperrealitas yang terjadi di masyarakat semakin terlihat melalui media sosial, terutama ibu-ibu di Desa Rengel. Hyperreality dibentuk oleh keberadaan media sosial untuk ibu rumah tangga untuk mendapatkan pengakuan diri melalui Facebook. Tujuan dari penelitian ini adalah untuk menganalisis pengenalan diri ibu rumah tangga menggunakan Facebook di Desa Rengel, Kabupaten Tuban. Teori yang digunakan adalah teori Hyperreality Jean Baudrillard bahwa hyperreality adalah gejala dari munculnya berbagai realitas buatan yang lebih nyata dari aslinya. Metode yang digunakan dalam penelitian ini adalah penelitian kualitatif dengan pendekatan studi fenomenologis. Teknik pemilihan subjek dalam penelitian ini menggunakan purposive sampel, sumber data dari penelitian ini menggunakan data primer dan data sekunder. Analisis data menggunakan reduksi data, model data, menyimpulkan. Dan pengujian validitas data menggunakan triangulasi. Hasil penelitian menunjukkan ibu rumah tangga mendapat pengakuan diri melalui berbagai cara, yaitu melalui unggahan foto menggunakan kamera yang indah sehingga hasilnya terlihat sempurna dari kenyataan, melalui status Facebook yang menunjukkan kehidupan sehari-hari agar mendapat tanggapan dari pengguna Facebook lain, melalui foto harian kegiatan agar pengguna Facebook lainnya mengetahui apa yang sedang dilakukan setiap hari dan mendapat tanggapan dari pengguna Facebook lainnya. Melalui foto yang ditandai ada berbagai produk kecantikan agar lebih tertarik sebagaimana pada produk yang ditawarkan.
\end{abstract}

Kata kunci: hiperrealitas, facebook, pengakuan diri 
Dam ayanti, Hidayat: Hiperreality Of

Social Media: A Phenomenology Study of

Self Confession of Housewives of

Facebook Users

\section{INTRODUCTION}

At this time the development of the internet began to penetrate and get a strong position in the mass media that first existed. The internet has been considered as a place to visit for people who are technology literate (Komala 2018). The internet has a role as a new medium with interactive excellence and building relationships in a person, group and mass manner (Astuti 2015). When the Internet began to be known to the public around ten years ago, it was predictable, this media would be very popular in the future. This was also seen when computer devices, both hardware, and software, continued to develop and were refined every minute in computer factories, so far the public's response to this media was very enthusiastic (Bungin 2011).

The development of communication technology as an unavoidable thing. This affects the change in the way humans interact (Meilinda 2018). Besides, technological advances are also able to influence the point of view of human life. From the advances in information technology, the mass media presents a variety of online applications that can be accessed by all the general public. people are more free to express themselves through social media than in the real world. This causes hyperreality. Hyperreality itself is a human unconsciousness to distinguish between reality and fantasy so that truth, authenticity, falsehood, facts, or lies are very difficult to distinguish (Tuela 2017).

Hyperreality or pseudo-reality is the reality that is produced and the reproduction of objects with references to objects that are not real. Hyperreality will replace the original reality so that the original reality will not be visible (Maulina 2018).Only symbols that appear in hyperreality.

This hyperreality has gradually melted on the sidelines of real-life and the effect of this hyperreality is that people are increasingly fond of social media, for example, Facebook users who are now accessible to all groups from children, teenagers to mothers. This can be accessed at any time even humans today communicate more often through social media than directly communicating. Social media users are more engrossed in interacting in cyberspace, besides that through social media they can also find new friends (Marlina 2016). 
Social media is an online media, with its users, can easily participate, share and create content including blogs, social networks, wikis, forums, and the virtual world. Social media is also a product of the development of science and technology (Febriana 2017). Social media is intended to share among individuals to achieve a better quality of life. The largest social networks include Facebook, Myspace, and Twitter. If traditional media uses print and broadcast media, then social media uses the internet. Social media invites anyone interested to participate by contributing and feedback openly, giving comments, and sharing information in a fast and unlimited time.

Facebook is one of the most well-known social media because it is easy to access and can be connected worldwide. Facebook is a friendship site that is developing very fast and offers many user-friendly features, where users can join and connect with other communities (Madrah 2014). Facebook displays a complete profile of yourself with photos, socializing with people who have the same hobby, becoming an artist-fan, sharing stories and activities, or chatting online with other users (Ramdhani 2016). Facebook can be interpreted as an advanced book. Even so, understanding Facebook is not just a site that provides information in the form of a user's advance book.

More than that, Facebook is a site that presents social networking services where users can interact with other users from all over the world. In this social networking site, users can upload various information about themselves, so other Facebook users can find out the information to get to know the owner of the account. Not only that, Facebook account users can also comment on each other's various status posts or other information that they share on this social networking site.

In Rengel Village, Tuban Regency, the majority of people using Facebook accounts are housewives who already have children. They use Facebook accounts to show their daily lives, express their daily life complaints through Facebook status, they can communicate with Facebook for about 1 to 2 hours. This shows that mothers today are more active in cyberspace, which is a world that is loved today is only a world of illusion.

Mothers in Rengel Village use Facebook accounts only to show their selfexistence in cyberspace and to gain self-recognition through Facebook's social media that can be said to be cyberspace, so it is inversely proportional to the real 
Damayanti, Hidayat: Hiperreality Of

Social Media: A Phenomenology Study of

Self Confession of Housewives of

Facebook Users

world that they only carry out daily household activities. days like taking care of children, home and husband. But in reality, in the virtual world, they are desperately showing hyperreality that is considered real as a form of selfexpression to get self-recognition from Facebook.

The hyperreality shown by Facebook users is part of her engineering, the engineering made by Facebook users is that they use HP to photograph themselves using a beautiful camera so that the results they get are maximized and then they upload a photo of themselves on Facebook, so it's no wonder if the photos that are shared on Facebook look more beautiful or perfect compared to the original face. With a variety of short descriptions that they write in their posts, they hope to get sympathy from other Facebook users, such as likes and comments.

In addition to the photos that are shared they also update the status of their daily lives, personal lives, or complaints that they experience, this shows that the virtual world like Facebook looks more real than the real world, the real world they show is just a mere fantasy world (Anwar 2018).Personal life that should not be consumed by the public, now they are not reluctant to show it on social media, even social media can be used as a venue for vent to some Facebook users.

Like housewives in Rengel Village, they are not awkward with what is posted on Facebook, just to show their daily lives and to get self-recognition from other Facebook users. Self-recognition itself is a desire to be recognized by normal humans. Someone will do something or find something new to be recognized by others and good self-recognition is self-recognition from others. In addition to the real world, self-recognition can also be obtained through social media to show their identity as a sign that they can become someone who deserves public recognition.

Previous research Thesis by Hilda Reshtyanti, Department of Sociology Department, Faculty of Social and Political Sciences, Airlangga University with the title "Self Imaging in Social Media Path (Descriptive Study on Students of SMA Negeri 2 Surabaya)", 2016. Which research aims to find out how a teenager uses social media Path to shape his image by using the study of the theory of Hyperreality as a knife for his analysis. This research is a qualitative study, to 
explain more deeply about students who represent themselves in social media Path. The technique of determining informants using Snowball is the initial source of data retrieval which gradually becomes large, while the data collection technique uses primary data obtained from interviews and observations and also uses secondary data, namely books, journals, and articles. The results of this study reveal that Path helps them to form new identities following what is needed and desired. Users can construct and create their self-image through the profile photos they use, the places they visit, the movies they watch, the songs they listen to, how many likes and comments they get at each moment they share. Being a popular person is the image they want to build in their Path account. The difference in this research lies in the focal point and the use of the approach.

\section{METHODS}

In a study entitled "Social Media Hyperreality (Phenomenology Study of Self-Confession of Facebook Users Housewives in Rengel Village, Tuban Regency" using qualitative research. Qualitative research is research that emphasizes process and meaning. Not to the collection and causal relationship between various variables (Sugiyono 2014). In research, researchers choose to use qualitative research methods to reveal problems that need deepening. By using a phenomenological approach. The phenomenological approach is a thinking perspective that emphasizes the focus that illustrates the meaning of a human life experience about a concept or phenomenon, people who are involved in a phenomenon do an exploration of the structure of awareness of human life experience (Moleong 2006).

Phenomenology attempts to describe the phenomenon as it appears to the observer. Symptoms in question are both symptoms that can be directly observed by the senses (external symptoms), as well as symptoms that can almost be experienced, felt, imagined, or thought by the observer without the need for empirical references (internal symptoms).

Furthermore, the type of data used in this study is primary data where the source of the data is data obtained directly from the source, the second then uses secondary data types obtained from journals, books, internet, etc. The data collection method uses the first method, which is observation, which is conducted in a participatory way by researchers trying to look deeper into what is being done 
Dam ayanti, Hidayat: Hiperreality Of

Social Media: A Phenomenology Study of

Self Confession of Housewives of

Facebook Users

on the informants' Facebook accounts. The second interview, to get more complete data from the informants studied.

When this research was conducted in early January 2019, the data taken by researchers were used as material for research in Rengel Village, Tuban Regency to obtain valid data from the informants under study. Furthermore, the last is documentation, which is in this study is taking pictures by researchers to strengthen research results. The method of determining the subject informant was chosen based on a purposive sampling technique. With the criteria of the informants as follows: (1) the informants are housewives who are actively using Facebook (2) informants aged 27-48 years (3) the informants are native residents of Rengel Village (4) the informants are housewives who are married and have children who actively use Facebook.

Data analysis methods that have been collected in the field, the researcher must explain and explain it well to become a writer. Hereby, the researcher refers to what is explained by Miles and Huberman, as quoted in Sukmadinata, which consists of three stages, namely: Data reduction, data display, and conclusion drawing or verification (conclusion drawing/verification), or can be called the analysis model (Emzir 2014).

The method of checking the validity of the data uses triangulation, in which the triangulation itself is a process of checking the validity of the data using something outside the data for checking or comparison purposes. Here the researcher uses source triangulation.

In conducting the study and discussion of this thesis the author uses the theory put forward by Jean Baudrillard. Baudrillard divides four terms in hyperreality namely simulation, mass media, signs, and communication(Fitria 2015). Hyperreality does not match real conditions so hyperreality only refers to oneself (Peristiwati 2015).Hyperreality is freely interpreted as a symptom of the presentation of artificial reality that reality exceeds the actual reality in the real world (Handayani 2018). According to Jean Baudrillard, hyperreality is a symptom of the emergence of various artificial realities that are even more real than the real. Not only more real, hyperreality is also more ideal or better than the original (Hidayah 2014).Hyperreality is a reality that transcends itself and because 
it transcends itself, it is no longer like its original reality (Margaretha 2011). Imagery is more convincing than facts and dreams are more believable than everyday reality. The world of hyperreality is a reality that is more real than real and is pseudo (Mardani 2014).

Hyperreality Discussion about hyperreality is closely related to how we position ourselves or see ourselves ontologically among so many objects. This also relates to how humans construct images and arrange their meaning by reflecting on mass media objects. How humans see themselves is the same as how they view their world. The world is a mirror of the human self (Margaretha 2011). In the discourse about the world in the current era of global capitalism, both objects and mass media are pseudo realities. Pseudo-reality is related to information technology, commodities or objects, and spectacles (Margaretha 2011).

Researchers use the theory of hyperreality because today's society interacts more through social media, especially mothers of Facebook users who every day use Facebook accounts to get self-recognition on Facebook's social media, by using various methods, namely uploading photos with perfect results with using a beautiful camera or using a filter, besides uploading photos of housewives, they also frequently update their life status, with friends or with family. This has become a symptom of hyperreality that has penetrated among people who like to use a Facebook account, everything posted exceeds the reality in real life. Because in the virtual world there is nothing original, but housewives assume that Facebook is like the real world for him.

In a study entitled "Social Media Hyperreality (Phenomenology Study of Self-Confession of Facebook Users Housewives in Rengel Village, Tuban Regency" using qualitative research.Qualitative research is research that emphasizes process and meaning. Not to the collection and causal relationship between various variables (Sugiyono 2014). In research, researchers choose to use qualitative research methods to reveal problems that need deepening. By using a phenomenological approach. The phenomenological approach is a thinking perspective that emphasizes the focus that illustrates the meaning of a human life experience about a concept or phenomenon, people who are involved in a phenomenon do an exploration of the structure of awareness of human life experience (Moleong 2011). 
Damayanti, Hidayat: Hiperreality Of

Social Media: A Phenomenology Study of

Self Confession of Housewives of

Facebook Users

Phenomenology attempts to describe the phenomenon as it appears to the observer. Symptoms in question are both symptoms that can be directly observed by the senses (external symptoms), as well as symptoms that can almost be experienced, felt, imagined, or thought by the observer without the need for empirical references (internal symptoms).

Furthermore, the type of data used in this study is primary data where the source of the data is data obtained directly from the source, the second kemudin uses secondary data types obtained from journals, books, internet, etc. The data collection method uses the first method, which is observation, which is conducted in a participatory way by researchers trying to look deeper into what is being done on the informants' Facebook accounts. The second interview, to get more complete data from the informants studied.

When this research was conducted in early January 2019, the data taken by researchers were used as material for research in Rengel Village, Tuban Regency to obtain valid data from the informants under study. Furthermore, the last is documentation, which is in this study is taking pictures by researchers to strengthen research results. The method of determining the subject informant was chosen based on a purposive sampling technique. With the criteria of the informants as follows: (1) the informants are housewives who are actively using Facebook (2) informants aged 27-48 years (3) the informants are native residents of Rengel Village (4) the informants are housewives who are married and have children who actively use Facebook.

Data analysis methods that have been collected in the field, the researcher must explain and explain it well in order to become a writing. Hereby, the researcher refers to what is explained by Miles and Huberman, as quoted in Sukmadinata, which consists of three stages, namely: Data reduction, data display, and conclusion drawing or verification (conclution drawing / verivication), or can be called the analysis model (Emzir 2014).

The method of checking the validity of the data uses triangulation, in which the triangulation itself is a process of checking the validity of the data using something outside the data for checking or comparison purposes. Here the researcher uses source triangulation. 
In conducting the study and discussion of this thesis the author uses the theory put forward by Jean Baudrillard. Baudrillard divides four terms in hyperriality namely simulation, mass media, signs, and communication (Fitria 2015). Hyperreality does not match real conditions so hyperreality only refers to oneself(Peristiwati 2015). Hypereality is freely interpreted as a symptom of the presentation of artificial reality that the reality exceeds the actual reality in the real world (Handayani 2018). According to Jean Baurdrillard, hyperreality is a symptom of the emergence of various artificial realities that are even more real than the real. Not only more real, hyperreality is also more ideal or better than the original (Hidayah 2014). Hyperreality is a reality that transcends itself and because it transcends itself, it is no longer like its original reality (Margaretha 2011). Imagery is more convincing than facts and dreams are more believable than everyday reality. The world of hypereality is a reality that is more real than real and is pseudo (Mardani 2014).

Hypereality Discussion about hyperreality is closely related to how we position ourselves or see ourselves ontologically among so many objects. This also relates to how humans construct images and arrange their own meaning by reflecting on mass media objects. How humans see themselves is the same as how they view their world. The world is a mirror of human self (Margaretha 2011). In the discourse about the world in the current era of global capitalism, both objects and mass media are pseudo realities. Pseudo-reality is related to information technology, commodities or objects, and spectacles(Margaretha 2011).

Researchers use the theory of hyperreality because today's society interacts more through social media, especially mothers of Facebook users who every day use Facebook accounts to get self-recognition on Facebook's social media, by using various methods, namely uploading photos with perfect results with using a beautiful camera or using a filter, besides uploading photos of housewives, they also frequently update their personal life status, with friends or with family. This has become a symptom of hyperreality that has penetrated among people who like to use a Facebook account, everything posted exceeds the reality in real life. Because in the virtual world there is nothing original, but for housewives assume that Facebook is like the real world for him.

\section{RESULTS AND DISCUSSION}

In this discussion, the researchers describe the results of research in the field related to the problem with the title "Social Media Hyperreality 


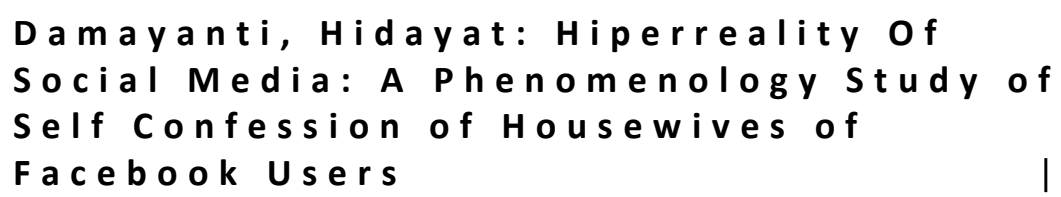

(Phenomenology Study of Self-Confession of Housewives Facebook Users in Rengel Village, Tuban Regency). The following is a self-confession of Facebook housewives in Rengel Village, Tuban Regency.

Reasons for housewives to use facebook.Based on interviews that have been carried out with informants underneath their reasons for using a Facebook account because this Facebook application is more easily understood by housewives, besides being easy to understand Facebook accounts serve as a venue for friendship with friends who have not seen each other for a long time and also the fame that coveted on social media can be obtained on Facebook.

Self-Confession Facebook Housewives.Desire to be recognized as something normal for a normal human being to do something or find something new to be recognized by others. Good self-recognition is a recognition that comes from other people, other people will admit someone is an expert when it has been tested. But, now many are looking for self-recognition from self-perception and forcing others to acknowledge. In addition to the real world, self-recognition can also be obtained through social media, which in today's society more and more exist in social media to show their true identity as a sign that they are capable of becoming someone worthy of public recognition.

Self-recognition obtained from Facebook merely wants to be recognized by other Facebook users that he deserves praise from others. Through many ways are shown by housewives on Facebook they use a beautiful camera, to get maximum results. The desired self-recognition from users of Facebook is only as simple as an eye to show that they look so perfect on social media so that other Facebook users will like to comment on the housewives of Facebook users.

No wonder that in this day and age many Facebook users want to get selfrecognition through Facebook which is just their fantasy world. As attached to the picture of the informant named UmmiHaniyah, the informant always exists on Facebook's social media which portrays herself as a beautiful and pleasing woman, because seen from her posts, she always appears confident when uploading photos, but before uploading the results herself to Facebook, the informant uses camera effects so that the resulting photo looks perfect in order to 
get a lot of responses from other Facebook friends, and get praise from other Facebook users.

Ways to Get Self-Confession Housewife on Facebook. In getting selfrecognition through Facebook, housewives have several ways so that the posts they post are able to get the attention of other Facebook users, besides the quality of posts posted must be able to attract the attention of all people, in order to get responses such as likes and comments that they think are already able to give attention to the posts that are uploaded. Housewives to get self-recognition have several ways, namely by uploading selfies and beautifying the results to be recognized by other Facebook users that she is indeed beautiful, and the second is to upload photos of daily activities carried out, the third by updating the status of his personal story that illustrates his life story, and the fourth, by updating the status or photos that are tagged in each activity in order to get the attention of other Facebook users who are not necessarily the people who pay attention to really care. From the explanation above, the researcher will discuss one by one out of 4 ways to get self-confession of housewives using Facebook as follows.

Through selfie photos.From the interview results generated various opinions from the informants to get self-recognition informants upload photos on Facebook with beautiful cameras that already equipped with filters so that the results obtained look more perfect, besides using makeup is also one way to get self-recognition through Facebook. The hyperreality shown by these mothers looks very real because the real reality is not following what is posted on Facebook.

Besides, getting self-recognition is not just a matter of beauty but shows that he looks improvised and shows harmony in the family is also one form of self-recognition that you want to get on Facebook so that other Facebook users admit that they are what they are and have a harmonious family. The hyperreality shown in the informant's upload is exaggerating the reality in his life.

When housewives post complaints about their lives on Facebook it is not uncommon to get attention from other Facebook users, wanting to get selfrecognition causes Facebook users to use any means to get perfect results if they update their status or upload their photos to get good feedback from other Facebook user friends. 


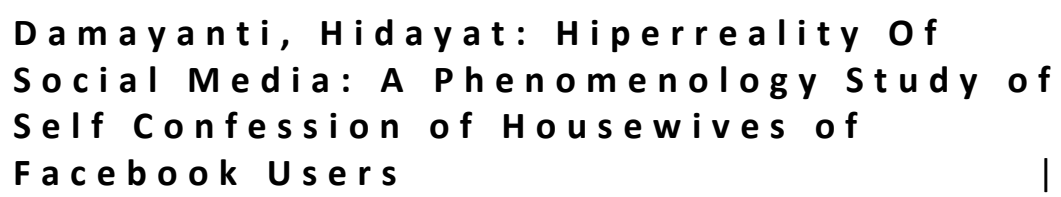

Through photos of everyday activities.In getting self-recognition, photos of daily activities also need to be shared so that other Facebook users know what is being done every day. In the world of Facebook, people often forget that the world that is loved is only the virtual world without realizing that humans already assume that the virtual world is like the real world. From the interview results, the informant shows that the virtual world is still the virtual world, not the real world that he has been living with, but some think that the virtual world is still the real world because friends on Facebook are real and there is no fake. Through photos of daily activities, informants share their daily activities so that other Facebook users know what is being done every day to get the attention of other Facebook users. The hyperreality shown in the informant's post is now increasingly visible because the social media that is loved now is more like its world.

Through the status of personal stories.In the world of Facebook to get selfrecognition from someone it is sometimes important to do a variety of ways so that other Facebook users recognize what is in him. Through the status shared on Facebook, housewives can get the attention of other Facebook users, they like to update the status of their complaints, their daily lives, and anything they feel can be shared on Facebook. This shows that hyperreality has penetrated the middle of society today, the reality that should be more real is now inversely proportional to the artificial reality that has been made by Facebook users.

From interviews with informants showed that after posting a complaint on Facebook to get their happiness felt by the informants, uploading status that smells of personal life often get a lot of likes and comments from other Facebook users, where they spread attention on every post from thirsty informants attention from cyberspace. Hyperreality stated in the informant's post that what was written in Facebook's status is not like the reality in the original, in other words, it's just setting it to get more attention from other Facebook users.

Facebook has been considered by most people as a second home, how can Facebook not become a place to gain self-recognition from various groups ranging from the young to the old one can enjoy Facebook everything can be posted in order to get more attention from other Facebook users, this is slowly to be a real hyperreality the world they like is a mere fantasy world and not real. 
Humans are creatures that want to be considered. In the human psychological pyramid, it is stated that the achievement and appreciation of others is the highest need after self-actualization. To get recognition and status, someone is motivated to do social interaction. Facebook, a virtual social network, allows one to get selfrecognition from other Facebook users.

Through status or photos marked.Facebook is a place to express themselves through status or Facebook. by uploading photos or status on Facebook Facebook users will feel much happier than telling stories with friends in the real world. In the world of hyperreality nothing is more real than the real reality, hyperreality is created by the existence of social media that supports it, so that what looks real is not really real on social media, because authenticity has fused and blended with the falsity that is in it, hyperreality is able to create the world which is ephemeral for connoisseurs of social media especially Facebook. So that Facebook can anesthetize millions of people in the world who use Facebook accounts to sink into it. In addition to sharing photos and Facebook's private status, they are also able to tag posts from other people shared on other Facebook users. Various beauty and body slimming products are marked by many informants, besides motivational videos that can anesthetize informants as well as learn about the homepage of Facebook informants.

Perceptions in this study indicate that gaining self-recognition through Facebook, most of the opinion must be beautiful and pleasing to the eye, the camera used is beautiful so that the results of their selfie photos are more perfect than the actual reality. In using Facebook these housewives do not know the time at any time if you want to open Facebook, they do not even feel tired when it is associated with Facebook. There is a special pleasure that can not be explained when posting on Facebook especially if the posts they share get a lot of comments and likes from other Facebook friends, which they feel happy but can not be explained. Facebook has become like the real world for housewives. It can be seen from the posts they share that they always post complaints that they feel without thinking about what the impact would be if their posts were hit by bullies from their friends.

The hyperreality shown in the status or marked photo shows that on social media like Facebook must have a perfect and beautiful appearance so that other Facebook users pay more attention to informants, besides sharing videos that can 


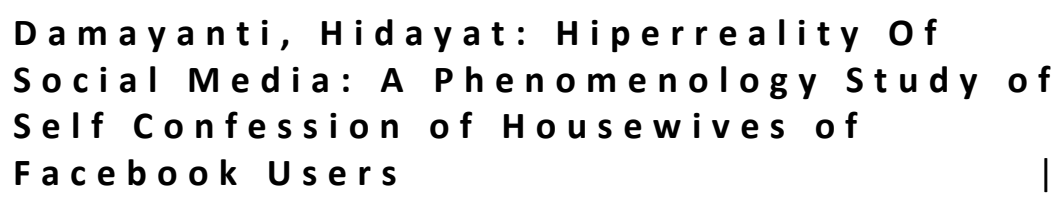

touch informants' hearts is one form of hyperreality that is seen real, because not necessarily the video shared is the actual video.

Hyperreality seems to have been firmly implanted in them, the reality that should have been is now fused with the falsehood they created themselves, the reality that should be more real, is now replaced by a more convincing fantasy than the real reality. But the best possible communication is face to face with the speaker, social media is just a world that is only a fantasy in it.

\section{CONCLUSION}

From the results of the research carried out conclusions can be drawn as follows:

1. Hyperreality self-recognition of Facebook users to housewives looks so real the article of a housewife who should only take care of household life has now become existed on Facebook social media.

2. Housewives in Rengel village are more fond of playing Facebook and showing their daily life through selfies, photos of daily activities, shared personal status, status tagged by other Facebook users.

3. From the research results obtained photos uploaded on Facebook using a beautiful camera or filter so that the results obtained are more perfect than the reality in the original.

4. After posting on Facebook, housewives in Rengel village feel their happiness, because the posts they share always get likes or comments from other Facebook users, this is considered as the attention they get from cyberspace friends.

5. For housewives of Facebook users, Facebook is still in cyberspace, because it is not necessarily the way it is in reality, but not all assume that Facebook is cyberspace, there are those who assume that Facebook is the real world because informants actually interact with Facebook users, and sometimes meet other Facebook users in person.

Based on the results of the research that has been done, the researcher gives a suggestion. Suggestions addressed to the interests of academics, and the community: 
1. To the people of Regel Village, they must be smart to use Facebook social media, especially in terms of their self-exclusion so there is no misuse of photos, status and anything shared on Facebook.

2. Sociologically, the researchers hope that this research can add insight into the social media hyperreality of housewives to gain self-recognition, which is engaged in the field of sociology.

3. Researchers hope that further research can more clearly examine in detail about social media hyperreality, researchers hope that further research can find interesting facts in the field by research with the same problem.

\section{REFERENCES}

Anwar, Khairil. 2018. "Mediatisasi Rupa Kota Dalam Iklan Meikarta Spectacle, Hiperealitas Dan Simulakra." Journal Communication Spectrum 8(2):14765 .

Astuti, Yanti Dwi. 2015. "Dari Simulasi Realitas Sosial Hingga Hiper-Realitas Visual: Tinjauan Komunikasi Virtual Melalui Sosial Media Di Cyberspace." Jurnal Komunikasi 08(02):15-26.

Bungin, Burhan. 2011. Kontruksi Sosial Media Massa. Jakarta: Prenada Media Group.

Emzir. 2014. Metodologi Peneltian Kualitatif Analisis Data. Jakarta: PT.Raja Grafindo Persada.

Febriana, Merri. 2017. "Hiperrealitas 'Endorse' Dalam Instagram Studi Fenomenologi Tentang Dampak Media Sosial Di Kalangan Mahasiswa Universitas Sebelas Maret.” Jurnal Analisa Sosiologi 6(2):18-29.

Fitria, Herlinda. 2015. "Hiperrealitas dalam Social Media (Studi Kasus Makan Cantik di Senopati pada Masyarakat Perkotaan)." Jurnal Informasi Kajian Ilmu Komunikasi 45(2):87-100.

Handayani, Dwi Asih. 2018. "Hiperbola Dan Hiperrealitas Media Analisis Judul Berita Hiperboa Di Situs Berita Online.” Jurnal Dialektika 5(2):121-34.

Hidayah, Nurul. 2014. "Gaya Hidup Konsumtif Mahasiswi Pengguna Perawatan Wajah Di Klinik Kecantikan Kota Surabaya.” Jurnal Paradigma 02(02):1-8.

Komala, Elly. 2018. "Media Sosial Sebagai Sebuah Ruang Hiperealitas.” Jurnal LINIMASA 1(2):1-15.

Madrah, Muna. 2014. "Identitas Diri Remaja Melalui Status Sosial Facebook." Jurna Ilmiah Komunikasi 4(2):181-98. 


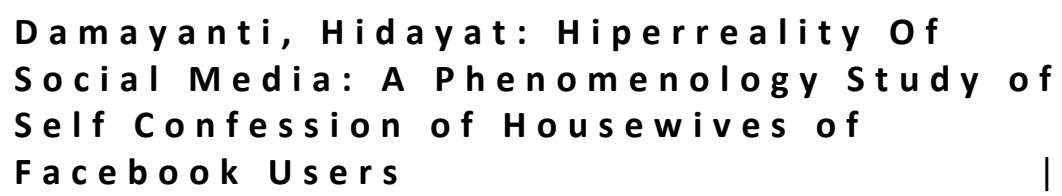

Mardani, Akh. 2014. "Praktik Konsumtif Mahasiswa Kangean Di Surabaya (Kajian Simulakra, Simulasi Dan Hiperrealitas J.P. Baudrillard).” Jurnal Paradigma 02(03):1-6.

Margaretha, Kushendrawati dan Selu. 2011. Hiperrealitas Dan Ruang Publik: Sebuah Analisis Culture. Jakarta: Penaku.

Marlina. 2016. "Daya Tatik Fasebook sebagai Media Komunikasi Alternatif." Journal Al-Baligh 1(1):105-25.

Maulina, Putri. 2018. "Warung Kopi, Masyarakat Virtual, Dan Hiperrialitas (Ketika Warung Kopi Mengaburkan Batasan Realita).” Journal Source 4:2637.

Meilinda, Nurly. 2018. "Social Media On Campus: Studi Peran Media Sosial Sebagai Media Penyebaran Informasi Akademik Pada Mahasiswa Di Program Studi Ilmu Komunikasi FISIP UNSRI." The Journal of Society \& Media 2(1):53-64.

Moleong, Lexi J. 2006. Metodologi Penelitian Kualitatif. Bandung: PT Remaja Rosadakarya.

Peristiwati, Maria. 2015. "Hiperrealitas Online Shop dan Tindakan Konsumtif Melalui Jejaring Sosial Online.” Jurnal Mahasiswa Sosiologi 1(5):1-15.

Ramdhani, Muhammad. 2016. "Pengaruh Sosial Media (Facebook) Terhadap Prestasi Belajar Mahasiswa Ilmu Komunikasi Universitas Singaperbangsa (Unsika) Karawang.” Jurnal Politikom Indonesiana 1(1):66-76.

Sugiyono. 2014. Metode Penelitian Kuantatif Kualitatif, Dan R\&D. Bandung: Alfabeta CV.

Tuela, Michael. 2017. "Hyperreality: Pemaknaan Dalam Penggunaan Game Pokemon Go.” Jurnal Kajian Media 1(1):1-15. 